\title{
The Mucopeptides of Bacterial Cell Walls. A Review
}

\author{
BY ELIZABETH WORK \\ Troyford Laboratories, Troyford Abbey Road, London, N.W. 10
}

(Received 11 October 1960)

The cell walls are rigid insoluble structures of bacteria. Attempts at isolating walls were first made last century (Vincenzi, 1887), and there was much speculation about their chemical nature-chiefly as to whether they consisted of chitin or cellulose, materials known to provide rigid structures in other organisms. Even 10 years ago practically nothing could be said on the subject except that the walls were not chitin or cellulose. Since then we have achieved at least the beginning of an answer (see Reviews, Salton, 1956 $a$; Work, 1957; Zilliken, 1959); but it will be long before we have the full story for all types of bacteria. The first information about the chemical constituents of bacterial walls was in a report by Holdsworth (1951) that phenol-insoluble residues from Corynebacterium diphtheriae contained nearly all the glucosamine and $\alpha, \epsilon$-diaminopimelic acid of the organism, and that these compounds were associated with a polysaccharide. The perfection of techniques for preparation of walls (Salton \& Horne, 1951), by mechanical disintegration and differential centrifugation, enabled apparently homogeneous samples to be examined. Walls of streptococci were shown simultaneously by Salton (1952a) and McCarty (1952) to contain about $70 \%$ of polysaccharides and hexosamines and a further component consisting of only 10 amino acids, of which lysine, alanine and glutamic acid preponderated. Rhamnose was the main polysaccharide; in fact, over $90 \%$ of the total rhamnose of the cell was in the wall. Further work by Salton showed that walls of other species also had an unusual composition, which was not then understood.

The problem was attacked systematically by Cummins \& Harris (1956 $a, b, 1958$; Cummins, 1956) who examined walls of over a hundred Gram-positive bacteria. The separated walls were treated with trypsin and ribonuclease, and were thus freed from wall proteins and cytoplasmic constituents. A resistant residue was left; its main components, identified by paper chromatography of acid-hydrolysates, were invariably the two hexosamines glucosamine and muramic acid, and three amino acids, glutamic acid, alanine and either lysine or diaminopimelic acid; in some cases there were also up to five sugars, one or two other amino acids, or galactosamine. A recurring type of 'basal unit' in Gram-positive cell walls was soon recognized (Work, 1957). This 'basal unit' can be termed a 'mucopeptide'; evidence for its existence will be presented in this review. It contains the aforementioned hexosamines, glucosamine and muramic acid, and three amino acids bound in peptide linkage. In addition, each bacterial genus and even each species often has a characteristic pattern of amino acids, amino sugars and sugars superimposed on the basal mucopeptide unit. This pattern may prove of value in bacterial classification. 
The basal unit was apparent from the results of Cummins \& Harris, because they had, so to speak, stripped the meat off the walls with enzymes, leaving only the rigid framework. However, these results give an over-simplified idea of cell-wall structure, and it should be realized that freshly separated walls of Gram-positive organisms may contain up to $40 \%$ of their weight of protein and other compounds. For example, the teichoic acids, which are polyribityl phosphates, were found by Armstrong et al. (1958) to make up as much as $30 \%$ of the walls of certain Grampositive organisms. The walls or 'coats' of bacterial spores also contain mucopeptide units with considerable proportions of proteins and other unidentified substances (Strange \& Powell, 1954; Strange \& Dark, 1956; Salton \& Marshall, 1959).

The walls of Gram-negative bacteria are more complex than those of Grampositive bacteria; in addition to polysaccharide, the trypsin-treated walls contain a high proportion of lipid and most of the amino acids found in proteins (Salton, 1956a). The specific mucopeptide constituents, glucosamine, muramic acid and diaminopimelic acid, are also present, but their overall concentrations are lower than in the walls of Gram-positive organisms. The walls of Escherichia coli appear to have three layers visible with the electron microscope (Kellenberger \& Ryter, 1958). Chemically, they can be separated into an outer pliable lipoprotein coat very soluble in phenol, and an inner insoluble rigid layer containing mucopeptide constituents; a further less soluble constituent is a lipopolysaccharide which is probably the site of the O-antigen (endotoxin) (Weidel \& Primosigh, 1958; Weidel, Frank \& Martin, 1960; Westphal, 1960). The mucopeptide components are different from those of walls of Gram-positive bacteria in that they contain both diaminopimelic acid and lysine.

The rigidity and insolubility of at least part of the walls of nearly all types of bacteria suggest that the mucopeptide is highly polymerized and perhaps highly cross-linked. Owing to this insolubility, the chemical homogeneity of the rigid portions of wall preparations cannot be assessed, nor can chemical information on their undegraded structures be obtained directly. However, it is possible to purify soluble subunits of the rigid portions, and their analysis has produced evidence for the mucopeptide structures.

\section{Structure and metabolism of some specific constituents of mucopeptides}

Several constituents of bacterial mucopeptides have not been found elsewhere in nature, and may be specific to these structures. Muramic acid was isolated by Strange (1956) from a product obtained from the exudates of germinating spores of Bacillus megaterium; it is glucosamine in ether linkage through its 3-position with lactic acid (Strange \& Kent, 1959):

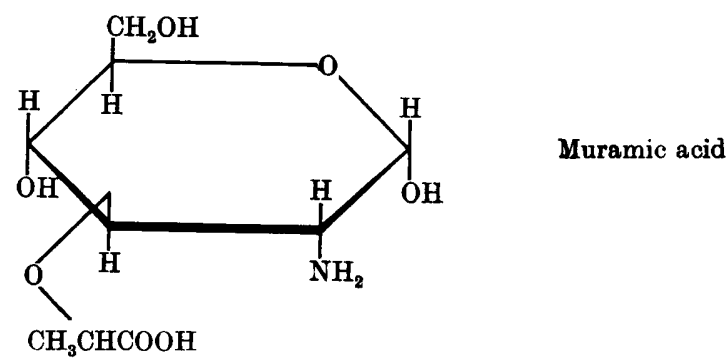


Muramic acid is a component of walls of all bacteria, but has not yet been identified in other types of organisms. It probably originates from glucosamine (Zillikin, 1959; Richmond \& Perkins, 1960c).

Whenever the optical configuration of the amino acids in Gram-positive cell walls has been examined, almost all the glutamic acid and at least $50 \%$ of the alanine have been identified as the so-called 'unnatural' D-isomers (Ikawa \& Snell, 1960; Salton, $1957 b$ ). D-aspartic acid has also been found (Toennies, Bakay \& Shockman, 1959), but never D-lysine. Rydon (1948) stated that D-amino acids are certainly present in bacterial extracellular products such as antibiotics or capsular polyglutamic acids, but that they had not been encountered in the intracellular components of micro-organisms. Now, only 12 years later, we know that certain Damino acids are major components of many bacterial walls, which themselves make up $25 \%$ or more of the total dry weight of the organisms. The origin of these $\mathrm{n}$ amino acids can be traced partly to the action of alanine racemase, a widely distributed bacterial enzyme. In Bacillus species, D-glutamic acid originates from L-glutamic by a series of reactions. A transamination between L-glutamic and pyruvic acids gives L-alanine, which is then racemized to the racemic mixture; of this, the D-alanine transaminates with $\alpha$-oxoglutarate to form D-glutamic acid and pyruvic acid (Thorne, Gomez \& Housewright, 1955; Thorne, 1956). The transaminase responsible for the last reaction is stereospecific, and will only carry out the reverse step with D-glutamic or D-aspartic acids, the L-isomers being inactive. A glutamic acid racemase has recently been isolated from Lactobacillus arabinosus (Glaser, 1960), but its significance in wall metabolism is unknown.

$\alpha, \epsilon$-Diaminopimelic acid is another compound specific to bacteria (see Review by Rhuland, 1960). It is not found in any other micro-organisms with the exception of the blue-green algae (Myxophyceae) which are closely related to bacteria. It is present in all bacteria, with the exception of most Gram-positive cocci and various lactobacilli (Work, 1951; Work \& Dewey, 1953; Hoare \& Work, 1957). Chemically diaminopimelic acid $\left.\begin{array}{l}\mathrm{COOH} \\ \mathrm{NH}_{2}\end{array}\right\rangle \mathrm{CH} \cdot \mathrm{CH}_{2} \cdot \mathrm{CH}_{2} \cdot \mathrm{CH}_{2} \cdot \mathrm{CH}\left\langle\underset{\mathrm{NH}_{2}}{\mathrm{COOH}}\right.$ is unlike most other naturally occurring amino acids in that it has $\mathbf{2}$ amino and 2 carboxyl groups. It has 3 stereoisomers, $\mathrm{LL}, \mathrm{DD}$, and one meso (DL) form, the molecule being symmetrical about the $\gamma$-carbon atom. The form which was originally isolated from Corynebacterium diphtheriae was optically inactive and was proved to be the meso isomer (Work et al. 1955). A solvent which will separate the meso isomer from the other two on paper chromatograms has enabled the isomer present in any organism to be determined (Rhuland et al. 1955; Hoare \& Work, 1955). The meso form is that most commonly found, but in certain families, notably Propionibacteria, and many Streptomyces, the LL isomer is present; a few organisms contain both meso and LL forms (Hoare \& Work, 1955, 1957). The findings of Cummins \& Harris and of Salton on distribution and isomeric form of diaminopimelic acid in cell walls of various species are identical with our results on whole bacteria. In fact, the majority of the cellular diaminopimelic acid is located in the wall, although small amounts are sometimes found in soluble fractions.

Diaminopimelic acid undergoes the general types of metabolic reactions which occur with other amino acids. The meso and LL isomers are attacked by certain L-amino acid oxidases (Work, 1955); some more specific bacterial enzymes decarboxylate, racemize, oxidize or transaminate one or other isomer (Dewey \& Work, 
1952 ; Dewey, Hoare \& Work, 1954; Antia, Hoare \& Work, 1957; Meadow \& Work, 1958; Antia \& Work, 1961). The racemase and decarboxylase have been studied in detail.

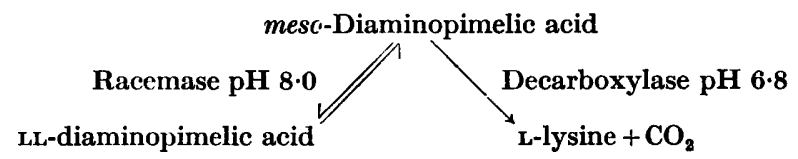

Diaminopimelic racemase converts either the meso or LL isomer to an equilibrium mixture of the two, while the decarboxylase converts meso-diaminopimelic acid to L-lysine with evolution of 1 molecule of $\mathrm{CO}_{2}$. Thus, meso-diaminopimelic acid is attacked by these two enzymes at the $D$ 'end'; this is the only known enzymic decarboxylation of a carboxyl group in the D-configuration. Since the DD isomer is not attacked by either enzyme, the L-configuration at one end of the molecule is evidently essential for fixation to the enzymes.

The bisosynthesis of diaminopimelic acid with cell-free preparations of various Escherichia coli mutants has been partly worked out (Gilvarg, 1957, 1958, 1959; Kindler \& Gilvarg, 1960; Peterkofsky \& Gilvarg, 1959).
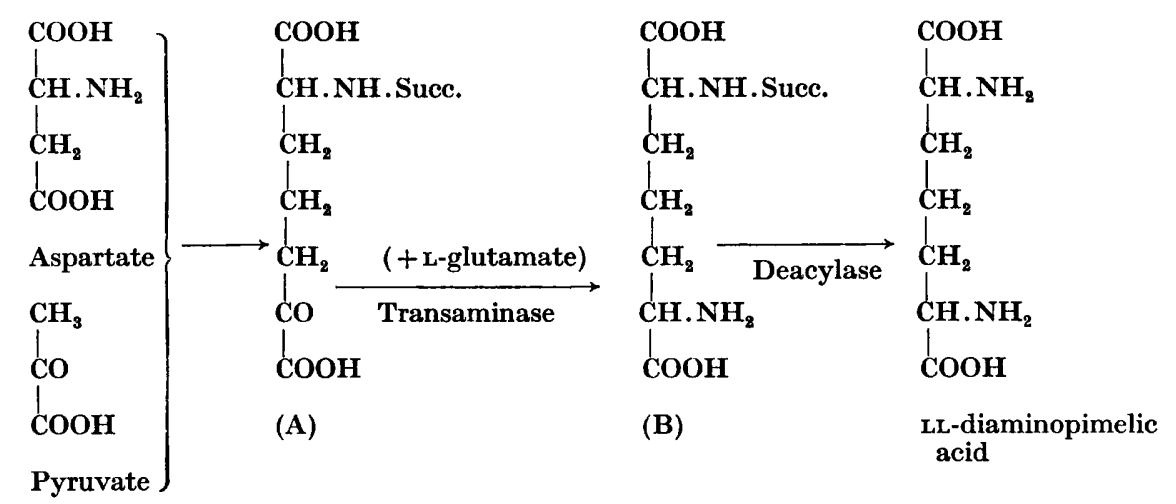

Some of these preparations can synthesize the amino acid from aspartic acid and pyruvic acid in the presence of glutamate, ATP and various cofactors. A monoketomonoamino acid (compound A) was identified as an intermediate: the amino group was derived directly from that of aspartate and was acylated with a succinyl radical. The acylation protects the molecule from cyclization, which would undoubtedly occur if the amino group were free to react with the keto group. A transamination with L-glutamate as specific amino donor results in the formation of $N$-succinylL-diaminopimelic acid (compound B), which is converted to LL-diaminopimelate by a specific deacylase. Since $E$. coli contains meso-diaminopimelic acid, the next step is probably racemization of the LL isomer. There are several lines of evidence that this step occurs in the whole organism (Hoare \& Work, 1955; Meadow, Hoare $\&$ Work, 1957), and a metabolic function for diaminopimelic racemase has been suggested.

The function of diaminopimelic decarboxylase is the formation of lysine. This was first established when it was found that certain mutants of Escherichia coli which require lysine lacked the decarboxylase (Dewey \& Work, 1952). Formal proof of in vivo conversion of diaminopimelic to lysine was obtained by examining the 
incorporation of radioactive diaminopimelic acid into the amino acids of growing cultures of $\boldsymbol{E}$. coli (Meadow \& Work, 1959). It was possible to trace the radioactivity from diaminopimelic acid to lysine, as excellent recovery of exogenous radioactive lysine was obtained in the cellular lysine. Also, radioautography showed that radioactive diaminopimelic acid was converted only into radioactive lysine, and that neither amino acid interchanged its carbon chain with other amino acids. To determine the proportion of lysine originating from diaminopimelic acid, two mutants of $\boldsymbol{E}$. coli were studied: one (173-25), had a relative requirement for lysine and an absolute requirement for diaminopimelic acid (Davis, 1952); the other (D), was derived from mutant 173-25 by 'training' it to dispense with lysine, when it required to be given only diaminopimelic acid (Meadow et al. 1957). The mutants

\section{Table 1. Summary of ${ }^{14} C$-incorporation experiments with diaminopimelic acid} $(\boldsymbol{D A P})$-requiring mutants of Escherichia coli

The organisms were grown in minimal media containing glucose $(0.5 \%)$, lysine $(0.1 \mathrm{~mm})$ and DAP $(0 \cdot 1 \mathrm{~mm})$. In each experiment one of these sources of carbon was radioactive (totally labelled). Phenol-insoluble fractions of walls were hydrolysed and the radioactivity of amino acids determined (Meadow \& Work, 1959).

Mutant 173-25 requires to be given lysine and DAP; mutant $D$ requires only DAP.

\begin{tabular}{|c|c|c|c|c|c|c|}
\hline \multirow[b]{2}{*}{ Expt. } & \multirow[b]{2}{*}{${ }^{14} \mathrm{C}$ source } & \multirow[b]{2}{*}{ Mutant } & \multicolumn{3}{|c|}{$\begin{array}{l}\text { Radioactivity of wall } \\
\text { amino acids }\end{array}$} & \multirow{2}{*}{$\begin{array}{l}\text { Radioactive lysine } \\
\text { as \% of total } \\
\text { lysine of fraction }\end{array}$} \\
\hline & & & DAP & Lysine & Others & \\
\hline 1 & DAP & $\begin{array}{l}173-25 \\
\mathrm{D}\end{array}$ & $\begin{array}{l}+ \\
+\end{array}$ & $\begin{array}{l}+ \\
+\end{array}$ & $\begin{array}{l}\mathbf{0} \\
\mathbf{0}\end{array}$ & $\begin{array}{l}80 \\
55\end{array}$ \\
\hline 2 & Lysine & $\begin{array}{l}173-25 \\
\mathrm{D}\end{array}$ & $\begin{array}{l}0 \\
0\end{array}$ & $\begin{array}{l}+ \\
+\end{array}$ & $\begin{array}{l}\text { 0 } \\
\text { 0 }\end{array}$ & $\begin{array}{l}10 \\
10\end{array}$ \\
\hline 3 & Glucose & $\begin{array}{c}173-2 \check{5} \\
\text { D }\end{array}$ & $\begin{array}{l}0 \\
0\end{array}$ & $\begin{array}{l}+ \\
+\end{array}$ & $\begin{array}{l}+ \\
+\end{array}$ & $\begin{array}{l}10 \\
20\end{array}$ \\
\hline
\end{tabular}

were grown in a basal salts and glucose medium with lysine and diaminopimelic acid, but in each experiment either the glucose, lysine or diaminopimelic acid was totally labelled with ${ }^{14} \mathrm{C}$. The cell walls were fractionated with phenol, and the insoluble portions, containing most of the mucopeptide, were hydrolysed and the proportion of the lysine originating from each carbon source was calculated (Table 1). Expt. 1 showed that labelled diaminopimelic acid was converted to lysine, but that it accounted for $80 \%$ of the total wall lysine in mutant $173-25$ which required to be given lysine for full growth, and only $\mathbf{5 5} \%$ in mutant $\mathrm{D}$. This difference between the two mutants was not accounted for by differences in their utilization of exogenous lysine, since they incorporated identical amounts of radioactivity from ${ }^{14} \mathrm{C}$-lysine (Expt. 2). When labelled glucose was used (Expt. 3), all the amino acids except diaminopimelic were labelled, and the mutant with no lysine requirement incorporated twice as much radioactivity into lysine as the other mutant. Expt. 3 proved that part of the lysine was derived from a route other than through diaminopimelic acid, and that there were at least two biosynthetic paths to lysine in $E$. coli. The major route is through diaminopimelic acid, while the other utilizes some unknown carbon source. The latter route was evidently strengthened by 'training' the mutant to dispense with added lysine, since the diaminopimelic decarboxylase activity was not changed by the process (Meadow et al. 1957). 


\section{Bacteriolytic enzymes}

Although the mucopeptides of bacterial cell walls are resistant to proteolytic enzymes (perhaps because of the presence of $D$-amino acids), they are often very susceptible to attack by bacteriolytic enzymes. The best known is lysozyme, first shown by Fleming (1922) to lyse living cultures of Micrococcus lysodeikticus, and later found to attack certain other living Gram-positive bacteria. Salton (1952 $b$ ) showed that the substrate for lysozyme is the cell wall itself; wall preparations from susceptible species are completely solubilized by lysozyme treatment, with a simultaneous decrease in optical density and the liberation of substances giving reactions for reducing sugars and $N$-acetylhexosamines (Reviews, Salton, 1957 $a, 1958$ ).

A so-called disaccharide has been identified in some lysozyme digests (Salton, $1956 b)$. It is probably a $\beta(1 \rightarrow 6)$ glycoside of $N$-acetylglucosamine and $N$-acetylmuramic acid, and is responsible for the reducing action of the digests. The reducing group belongs to muramic acid (Salton \& Ghuysen, 1959; Perkins, $1960 a$ ) so that the 1-carbon of glucosamine may be linked to the 6-carbon of muramic acid. Small amounts of a lysozyme-sensitive tetrasaccharide also occur in the digests; this may be a dimer of the disaccharide joined by $\beta(1 \rightarrow 4)$ linkages. Since free $N$-acetylglucosamine or $N$-acetylmuramic acid have not been found in digests, it seems possible that at least part of the mucopeptide molecule contains these compounds bound in pairs by lysozyme-sensitive $\beta(1 \rightarrow 4)$ linkages alternating with lysozymeresistant $\beta(1 \rightarrow 6)$ linkages; they might, in fact, form part of a backbone to which are linked peptides and polysaccharides. If this theory is correct, the $\beta(1 \rightarrow 4)$ glycosidic linkages in the backbone are the substrate for lysozyme. The susceptible links may be unevenly distributed along the backbone, since the fragments are of very different sizes and composition, some even have molecular weights up to 15,000 , and contain sugars, amino acids, muramic acid and glucosamine. There are great differences in susceptibility to lysozyme among various bacterial species. Little is known about the exact structure in walls which determines the extent of lysozyme sensitivity; no correlation has been found between overall composition and this sensitivity. All we know is that certain lysozyme-resistant organisms contain more $\mathbf{O}$-acetyl groups in their walls than do lysozyme-sensitive strains of the same organisms, and that the removal of these groups with mild alkali often renders the cells more sensitive (Brumfitt, 1959).

Most living Gram-negative bacteria are resistant to lysozyme, but they can be rendered susceptible by subjection to extremes of temperature or $\mathrm{pH}$ or by exposure to surface-active agents such as detergents, bile salts, chloroform, polymyxin or ethylene diamine tetra-acetic acid (EDTA) (see Review, Salton, 1958). These treatments probably all cause damage to the outer lipoprotein coat, and thus allow access of lysozyme to the inner mucopeptide substrate. Wall suspensions from Gramnegative bacteria when treated with lysozyme, show no appreciable changes in optical density, probably owing to their high content of non-mucopeptide constituents. Soluble constituents are, however, liberated from the walls; some contain diaminopimelic acid, alanine, glutamic acid, glucosamine and muramic acid (Salton, 1958; Work \& Lecadet, 1960).

Bacteriolytic enzymes are also produced by some bacteria. Many of these enzymes resemble lysozyme in their substrate specificity and in the nature of their 
digestion products (Richmond, $1959 a, b$ ); but there are often small differences of specificity and point of attack between the different enzymes, which are not yet understood. The bacteriolytic enzymes which do not resemble lysozyme were reviewed by Work (1957) and by Strange (1959). These enzymes have been found in the culture filtrates of certain Streptomyces species or associated with spores and vegetative cells of aerobic sporulating species of the genus Bacillus. The enzymes from spores are not entirely species-specific, although they are often more active towards walls of their own species; they will even attack walls of Gram-negative bacteria after treatments similar to those used for sensitization to lysozyme (Work, 1959). It has been suggested (Strange, 1959) that the lytic enzymes of species of Bacillus are involved in the sporulation cycle, since they are most active in the sporulating and germinating phases, when they release soluble mucopeptides from the sporangial wall or spore coat (Powell \& Strange, 1956).

The main mucopeptide released from germinating spores of Bacillus species has been isolated (Powell \& Strange, 1953; Strange \& Powell, 1954). It has a molecular weight of about 15,000 and consists mostly of 1 molecular proportion of D-glutamic acid, 3 of alanine ( $\mathrm{D}$ and $\mathrm{L}$ isomers), and 1 of meso-diaminopimelic acid, and a mixture of 8 molecular proportions of acetylglucosamine and acetylmuramic acid (Strange, 1959). This mucopeptide served as the original source of muramic acid. The mucopeptide is the only high-molecular-weight degradation product of wall mucopeptides to have been purified and analysed; the sequence of amino acids in it has not yet been established. It is further degraded by lysozyme and by $\beta$-glucosaminidase. Both glucosamine and muramic acid are present as the $N$-acetyl derivatives. This is the case with all the enzymic degradation products of walls so far examined (Salton, 1956 $b$; Salton \& Ghuysen, 1959; Perkins, 1960 $a, b$; Ghuysen \& Salton, 1960) and it may be assumed that the amino groups of these hexosamines are always acetylated.

Other lytic enzymes of bacteria are associated with the cell walls of vegetative organisms (Mitchell \& Moyle, 1957), and may be responsible for the rapid autolysis which sometimes occurs in dense suspensions of these organisms. Autolytic activity, if present, is stronger in rapidly growing cultures, and may play an active part in cell division, since localized breakdown of rigid cell-wall material might well occur immediately before division, followed by immediate resynthesis.

Lysis by bacteriophages. Lytic enzymes which attack cell walls are also associated with bacteriophages (Panijel \& Huppert, 1957; Koch \& Weidel, 1956; Maxted, 1957; Murphy, 1957; Koch \& Jordan, 1957; Brown \& Kozloff, 1957; Ralston, Lieberman, Baer \& Krueger, 1957; Krause, 1958; Koch \& Dreyer, 1958; Weidel \& Primosigh, 1957, 1958). Probably these enzymes are localized in the phage tails and are responsible both for the penetration of the phage infective principle through the bacterial rigid wall layer, and for the subsequent lysis of infected cultures (see review by Weidel, 1958). The lysates themselves often also show lytic activity. A defective lysogenic mutant $\left(\mathbf{P}_{32}\right)$ of Escherichia coli $\mathbf{K}_{12}(\lambda)$ produces a lysate which contains a lytic enzyme (Jacob \& Fuerst, 1958). Some of the properties of this enzyme (known as $\lambda$-endolysin) have been investigated after partial purification from a lysate induced by nitrogen mustard (Work, 1960). $\lambda$-Endolysin does not attack viable bacteria, even the host strain of $E$. coli, except after certain preliminary treatments, e.g. with chloroform, EDTA, acetone-drying. The bacteria 
are only susceptible during the exponential phase of growth. Many Gram-negative species are attacked, and even some Gram-positive species (Bacillus megaterium, Staphylococcus aureus). Micrococcus lysodeikticus, the substrate par excellence for lysozyme is not susceptible to $\lambda$-endolysin. Cell walls of $B$. megaterium are completely lysed by $\lambda$-endolysin, and have been used as substrate to examine its properties. The optimum $\mathrm{pH}$ value is about 7.0; some activation is produced by $\mathrm{NaCl}$ or $\mathrm{KCl}\left(10^{-2} \mathrm{M}\right)$. Phosphates and certain heavy-metal ions are strongly inhibitory, the amounts which give $50 \%$ inhibition (in presence of $\mathrm{NaCl}$ ) being $\mathrm{KH}_{2} \mathrm{PO}_{4}$, $10^{-3} \mathrm{M} ; \mathrm{Zn}, 5 \times 10^{-4} \mathrm{M} ; \mathrm{Fe}^{+++}, 10^{-5} \mathrm{M} ; \mathrm{Co}^{++}$and $\mathrm{Mn}^{++}, 10^{-3} \mathrm{M}$ no inhibitions, $\mathrm{Co}^{++}$ stimulates slightly. In the complete absence of heavy metals, EDTA is without effect but was usually added to walls before treatment with the endolysin as a protection against inhibitory metal ions. $\lambda$-Endolysin resembles the lytic enzyme of disrupted mature phage $\lambda$ (Fisher, 1959), but it differs from lysozyme in its sensitivity to metals and phosphates and in its specificity. Thus, $\lambda$-endolysin is distinct from the lytic enzyme of $\mathbf{T}_{2}$ coli phage or of lysates produced by the phage; this enzyme has been reported to resemble lysozyme (Koch \& Dreyer, 1958).

To provide further grounds for the comparison of $\lambda$-endolysin with lysozyme, the products of digestion by these enzymes of walls of Escherichia coli B and Bacillus megaterium were examined (Work \& Lecadet, 1960). The soluble fragments were separated by dialysis into two fractions, each of which was treated with 1-fluoro-2:4dinitrobenzene and then subjected to paper chromatography or paper electrophoresis. The resulting yellow spots were eluted, hydrolysed and examined qualitatively for free and dinitrophenylated amino acids. The hexosamines appeared to be partially destroyed during the hydrolysis of the dinitrophenylated fragments, so that no conclusions could be drawn about their presence. However, in nearly all cases, glucosamine and muramic acid (one or both) were detected in the hydrolysates, as well as a limited number of amino acids, so most of the yellow fragments were probably mucopeptide in nature.

The fragments produced by $\lambda$-endolysin from Bacillus megaterium were indistinguishable from those produced by lysozyme. Five spots were obtained by paper chromatography (butanol-acetic acid solvent) from each of the dialysable digests (Table 2). The slower-moving spots contained mainly alanine and glutamic acid and had no identifiable end-amino groups; the more mobile spots were larger and also contained dinitrophenyl-alanine and mono-dinitrophenyl-diaminopimelic acid. In the non-dialysable fractions, which were separated by paper electrophoresis at pH 3.6, similar distributions of amino acids occurred in the various spots, except that here diaminopimelic acid was present with both amino groups bound as well as with one attached to dinitrophenol.

$\lambda$-Endolysin and lysozyme did not produce identical fragments from Escherichia coli walls (Table 3). The digests contained a variety of amino acids, including both lysine and diaminopimelic acid, also glycine, serine and aspartic acid in addition to alanine and glutamic acid. In the dialysable fraction, only glutamic acid was invariably present in all spots; in fact in one spot from the endolysin digest, it was the only major amino acid detected. None of the less mobile spots contained alanine; diaminopimelic acid and lysine were fairly randomly distributed, but only occurred together in spots which were obviously inhomogeneous (e.g. the immobile or most mobile ones). One spot from the endolysin digest contained very large amounts of 
alanine, while a neighbouring spot from the lysozyme digest contained nearly all the usual amino acids of a protein but no diaminopimelic acid. A colourless dialysable fragment in digests from both organisms was identified on paper chromatograms by the acetylhexosamine reaction; it was probably the dimer of $N$-acetylglucosamine and $N$-acetylmuramic acid studied by Salton $(1956 b)$ in lysozyme digests from Gram-positive organisms. In the non-dialysable fractions of $\boldsymbol{E}$. coli, the differences between the actions of the enzymes were not so marked as in the dialysable fractions, but they were apparent. Several spots contained both diaminopimelic acid and lysine, with either both or one of their amino groups bound, or with both free. Further purification of the material from these spots has not yet been done.

Table 2. Amino acid contents of some peptides in digests of walls of Bacillus megaterium, produced by $\lambda$-endolysin (of Escherichia coli $K_{12}(\lambda)$ lysogenic mutant $P_{32}$ ) or lysozyme

Identical samples of walls $(2 \mathrm{mg}$.) were digested with each enzyme under optimal conditions. The digests were separated by dialysis, and each fraction was dinitrophenylated with fluorodinitrobenzene. The dialysable fractions were spread on Arche 310 paper and irrigated with butanol + acetic acid + water $(4: 1: 1)$ solvent for 2 days; the non-dialysable fractions were subjected to paper electrophoresis on Whatman $\mathbf{3} \mathrm{MM}$ paper at pH 3.6, $500 \mathrm{~V}$ for $9 \mathrm{hr}$. After drying the papers, the yellow spots were each cut out, eluted, hydrolysed with $6 \mathrm{~N}-\mathrm{HCl}$ and examined qualitatively by paper chromatography for free and dinitrophenylated amino acids. Controls without walls were treated identically; they showed small amounts of a few amino acids (originating from the filter paper) which have been allowed for in presenting the results.

The figures in the columns represent the distances (cm.) travelled by each spot. The two enzymes produced fragments identical in mobility and amino acid contents.

\begin{tabular}{|c|c|c|c|}
\hline \multicolumn{2}{|c|}{ Dialysable fraction } & \multicolumn{2}{|c|}{ Non-dialysable fraction } \\
\hline $\mathrm{cm}$. & Amino acids & $\mathrm{cm}$. & Amino acids \\
\hline $2 \rightarrow 5 \cdot 5$ & Glu, Ala & $-1 \rightarrow-8$ & Glu, Ala \\
\hline $6 \rightarrow 12$ & Glu, Ala & $0 \rightarrow+11$ & $\begin{array}{l}\text { Dap, Glu, Ala, Gly, } \\
\text { DNP-Dap, DNP-Glu }\end{array}$ \\
\hline $13 \rightarrow 18$ & Glu, Ala & $+15 \rightarrow+22$ & Dap, Glu, Ala, \\
\hline $20 \rightarrow 27$ & $\begin{array}{l}\text { Glu, Ala, } \\
\text { DNP-Dap, DNP-Ala }\end{array}$ & & DNP-Dap, DNP-Ala \\
\hline $30 \rightarrow 42$ & $\begin{array}{l}\text { Glu, Ala, } \\
\text { DNP-Dap, DNP-Ala }\end{array}$ & $+24 \rightarrow+26$ & Glu, Ala \\
\hline
\end{tabular}

Certain conclusions can be drawn from the results. Not every peptide fragment in the digests contained all the amino acids of the whole walls. This is contrary to results so far reported about the products of action of various bacteriolytic enzymes, where the non-dialysable peptides, produced by enzymic digestion of fresh walls or those already treated with fluoro-dinitrobenzene have been reported to contain all the constituents of wall mucopeptides (Salton, 1956 $b$; Ingram \& Salton, 1957; Koch \& Dreyer, 1958). Digestion products from the action of $\lambda$-endolysin or lysozyme on dinitrophenylated walls of Escherichia coli and Bacillus megaterium were different from those produced from untreated walls (Work \& Lecadet, 1960); the former therefore cannot be regarded as normal reaction products. The marked differences between the reaction products produced by $\lambda$-endolysin and lysozyme 
Table 3. Amino acid contents of some peptides in soluble fractions of $\lambda$-endolysin (from Escherichia coli $K_{12}(\lambda)$ lysogenic mutant $\boldsymbol{P}_{32}$ ) or lysozyme digests of walls of F. coli $B$.

Samples (40 mg.) of walls were exhaustively digested with two successive portions of either enzyme in the presence of chloroform. After removal of insoluble products by centrifugation, digests were treated as in Table 2 . The spots in the two digests were not identical, and are listed separately. The figures in the columns represent the distances (cm.) travelled by each spot.

\begin{tabular}{|c|c|c|c|}
\hline \multicolumn{2}{|c|}{$\begin{array}{l}\lambda \text {-Endolysin products, } \\
\text { dialysable }\end{array}$} & \multicolumn{2}{|c|}{$\begin{array}{c}\text { Lysozyme products, } \\
\text { dialysable }\end{array}$} \\
\hline $\mathrm{cm}$. & Amino acids & $\mathrm{cm}$. & Amino acids \\
\hline $\mathbf{0}$ & Dap, Lys, Asp, Glu, Ser, Gly & & \\
\hline $4-5 \cdot 5$ & Dap, Glu, Gly & $3-5$ & Dap, Lys, Asp, Glu, Ser, Gly \\
\hline $6-7$ & Glu & $6 \cdot 5-7 \cdot 5$ & Lys, Asp, Glu, Ser, Gly \\
\hline $8-10$ & $\begin{array}{l}\text { Dap, Glu, Ser, Gly, Ala,* } \\
\text { DNP-Dap }\end{array}$ & $9-11$ & $\begin{array}{l}\text { Lys, Asp, Glu, Ser, Gly, Thr, } \\
\text { Ala, Val, Leu, Arg, Cys }\end{array}$ \\
\hline $16-18$ & $\begin{array}{l}\text { Lys, Asp, Glu, Ser, Gly, Val, } \\
\text { DNP-Lys, DNP-Ala }\end{array}$ & . & . \\
\hline 21-22 & Glu, DNP-Dap & 20-25 & $\begin{array}{l}\text { Lys, Asp, Glu, Ser, Gly, Thr, } \\
\text { Ala, Val, Leu }\end{array}$ \\
\hline $30-36$ & $\begin{array}{l}\text { Lys, Asp, Glu, Ser, Gly, Ala, } \\
\text { Val, Leu, Arg, DNP-Dap, } \\
\text { DNP-Lys, DNP-Glu, } \\
\text { DNP-Ser, DNP-Ala }\end{array}$ & $30-36$ & $\begin{array}{l}\text { Lys, Asp, Glu, Ser, Gly, Ala, } \\
\text { Val, Leu, Arg, DNP-Dap, } \\
\text { DNP-Lys, DNP-Glu, } \\
\text { DNP-Ser, DNP-Ala }\end{array}$ \\
\hline $\begin{array}{l}36-42 \\
\text { (solvent front) }\end{array}$ & $\begin{array}{l}\text { Lys, Asp, Glu, Gly, Thr, Ala, } \\
\text { Val, Leu, DNP-Dap, } \\
\text { DNP-Lys, Di-DNP-Lys, } \\
\text { DNP-Glu, DNP-Ser, DNP-Ala }\end{array}$ & $\begin{array}{l}36-42 \\
\text { (solvent front) }\end{array}$ & $\begin{array}{l}\text { Asp, Glu, Ser, Gly, Ala, } \\
\text { DNP-Dap, Di-DNP-Lys, } \\
\text { DNP-Glu, DNP-Ser, } \\
\text { DNP-Ala }\end{array}$ \\
\hline \multicolumn{4}{|c|}{ * Very large amount } \\
\hline \multicolumn{2}{|r|}{ non-dialysable } & \multicolumn{2}{|r|}{ non-dialysable } \\
\hline$-2 \rightarrow+2$ & $\begin{array}{l}\text { Lys, Asp, Glu, Ser, Gly, } \\
\text { DNP-Dap }\end{array}$ & $-2 \rightarrow+2$ & $\begin{array}{l}\text { Lys, Asp, Glu, Ser, Gly, } \\
\text { DNP-Dap }\end{array}$ \\
\hline$+8 \rightarrow+13$ & $\begin{array}{l}\text { Dap, Asp, Glu, Ser, Gly, Ala, } \\
\text { DNP-Dap }\end{array}$ & $+8 \rightarrow+13$ & Dap, Glu, DNP-Dap, \\
\hline$+17 \rightarrow+21$ & $\begin{array}{l}\text { Dap, Lys, Glu, Ser, Gly, Ala, } \\
\text { DNP-Dap, Di-DNP-Dap, } \\
\text { Di-DNP-Lys, DNP-Glu, } \\
\text { DNP-Ser }\end{array}$ & $+17 \rightarrow+21$ & $\begin{array}{l}\text { Dap, Lys, Glu, Ala, } \\
\text { DNP-Dap, Di-DNP-Lys, } \\
\text { DNP-Glu, DNP-Ser }\end{array}$ \\
\hline$+21 \rightarrow+26$ & $\begin{array}{l}\text { Dap, Glu, Ser, Gly, Ala, } \\
\text { DNP-Dap, Di-DNP-Dap, } \\
\text { DNP-Lys, Di-DNP-Lys, } \\
\text { DNP-Glu, DNP-Ser, DNP-Ala }\end{array}$ & $+21 \rightarrow+26$ & $\begin{array}{l}\text { Dap, Lys, Glu, Ser, Ala, } \\
\text { DNP-Dap, Di-DNP-Dap, } \\
\text { DNP-Glu, DNP-Ser, } \\
\text { DNP-Ala }\end{array}$ \\
\hline$+26 \rightarrow+28$ & $\begin{array}{l}\text { Lys, Asp, Glu, Ser, Gly, } \\
\text { DNP-Dap }\end{array}$ & $+26 \rightarrow+28$ & Lys, Glu, Ser, Gly, DNP-I Jap \\
\hline
\end{tabular}

Ala $=$ alanine. $\quad$ Arg $=$ arginine. $\quad$ Asp $=$ aspartic acid. $\quad$ Cys $=$ cystine. $\quad$ Dap $=$ diaminopimelic acid. Glu = glutamic acid. Gly = glycine. Leu = leucine. Lys = lysine Ser $=$ serine. $\mathrm{Thr}=$ threonine. Val $=$ valine. $\mathrm{DNP}=$ dinitrophenyl group.

from $E$. coli walls show that the enzymes are not identical in their action on this material, although they appeared to act identically on walls from $\boldsymbol{B}$. megaterium. The reason for this is not known; it may be connected with the fact that walls of $E$. coli are the natural substrate for $\lambda$-endolysin. The lytic enzyme from $\mathbf{T}_{2}$ coli phage was reported by Koch \& Dreyer (1958) to resemble lysozyme in the fragments 
which were produced from dinitrophenylated walls of $\boldsymbol{E}$. coli B. Also, walls of $\boldsymbol{E}$. coli already digested by $\mathrm{T}_{2}$ coli phage enzyme were not further attacked by lysozyme, and vice versa. With $\lambda$-endolysin, on the contrary, the insoluble residues of dinitrophenylated walls of $E$. coli were further digested by lysozyme, while the lysozyme-resistant residues were also attacked by $\lambda$-endolysin. It is thus apparent that the lytic enzyme of $\lambda$-phage is different from that of $T_{2}$-phage. The results also indicated that $E$. coli walls are more complicated than was originally suggested by Weidel \& Primosigh (1958). Each of the so-called 'layers' contained mucopeptide components which are partially, but not entirely, solubilized by lysozyme or $\lambda$ endolysin; lipids were also solubilized and were even found in dialysable fractions. Apparently many structures are held together in these walls by non-covalent links which are broken as a secondary result of solubilization of the mucopeptides. Under the influence of lytic enzymes the walls disintegrate into many types of fragments which differ according to whether lysozyme or $\lambda$-endolysin is acting.

\section{The function of cell walls}

When whole susceptible organisms are treated with lysozyme or other bacteriolytic enzymes the rigid mucopeptide component of the cell wall is attacked, and the immediate cause of lysis is the bursting of the mechanically unprotected cytoplasmic membrane by the internal osmotic pressure. When the digestion is carried out in isotonic solution, e.g. $10 \%(\mathrm{w} / \mathrm{v})$ sucrose, the cytoplasmic membrane remains intact and spherical forms are produced (see review by Weibull, 1958). With Grampositive organisms the resulting bodies are known as protoplasts; chemical and immunological analyses have shown them to be free from wall components, including specific proteins and mucopeptides (Freimer, Krause \& McCarty, 1959; Vennes \& Gerhardt, 1959). Similar spherical bodies are produced from Gramnegative bacteria after appropriate preliminary sensitizing treatment, but cannot strictly be called protoplasts : not only do they still retain the wall lipoproteins and lipopolysaccharides, but they also contain mucopeptide components such as diaminopimelic acid and muramic acid (Salton, 1958); their membranes also react positively with cell-wall antibodies (Holme, Malmborg \& Cota-Robles, 1960). The term spheroplast is now usually applied to the spherical osmotically sensitive forms from Gram-negative bacteria (Brenner et al. 1958). Protoplasts and spheroplasts are reasonably stable in media of sufficiently high osmotic pressure; they burst when transferred to water, leaving a residue of membranous ghosts, similar in size to the original body. The composition of the ghosts (cytoplasmic membranes) from Gram-positive bacteria is quite different from that of cell walls; they contain considerable quantities of lipids, but no hexosamines, wall sugars or diaminopimelic acid (Gilby, Few \& McQuillen, 1958; Weibull \& Bergstrom, 1958). The permeability properties of protoplasts or spheroplasts are the same as those of the bacteria from which they were derived, showing that their membranes are the osmotic barrier of the intact cell. Protoplasts under appropriate conditions can synthesize protein, can grow, divide and produce bacteriophage after infection or induction (McQuillen, 1955; Borek \& Ryan, 1959). Thus they contain the main essential biosynthetic mechanisms of the cell, for which the wall mucopeptides are apparently not required when protection from osmotic effects is provided. Cell walls are permeable to dextrans of molecular weight up to 100,000 and to proteins excreted by the organisms, 
suggesting that they have a sieve- or sponge-like structure. Their main function would appear to be that of a rigid porous envelope which protects the delicate cytoplasmic membrane within. Gerhardt (1959) and Butler, Crathorn \& Hunter (1958) obtained evidence which suggests that certain amino acids may be stored in the walls; so walls may have the further function of a reservoir for certain metabolites.

Since the cell walls of all bacteria contain this specific mucopeptide structure, one ought to be able to prevent wall synthesis by growing exacting organisms in the absence of one of the mucopeptide components necessary for growth. This has been done with diaminopimelic acid (Meadow et al. 1957; Rhuland, 1957), lysine (Toennies \& Shockman, 1958) and glucosamine (Zilliken, 1959). Meadow et al. (1957) used the two mutants of Escherichia coli (173-25 and D, see p. 171) which require to be given diaminopimelic acid for growth. When grown in glucose salts media supplemented with a constant (optimal) amount of lysine, and different amounts of diaminopimelic acid, cultures of mutant 173-25 had initial growth rates which were independent of the diaminopimelic acid concentration. Organisms grown in media with low concentrations of diaminopimelic acid lysed when the diaminopimelic acid was exhausted from the medium. Mutant $\mathrm{D}$, grown in a similar series of media but without lysine, did not lyse, but just stopped growing when the diaminopimelic acid was used up. When lysine was present, lysis occurred on cessation of growth as with the cultures of mutant 173-25. This lysis can be explained on the basis that, provided some diaminopimelic acid is present, the organisms grow normally and form walls; as soon as the diaminopimelic acid is exhausted, new walls cannot be formed and the organisms burst, probably at the next division. The reason for the obligatory presence of lysine for lysis to occur is not known: it is not due to the fact that lysine allows cytoplasmic protein synthesis to continue so that the cell contents outgrow their walls (suggested by McQuillen, 1958a), since lysine can be replaced by $\alpha-N$-acetyllysine as a growth factor, and in this case lysis does not occur.

When these diaminopimelic-requiring mutants are grown in the presence of sucrose and low concentrations of diaminopimelic acid, spheroplasts are formed (Meadow et al. 1957; Bauman \& Davis, 1957; McQuillen, 1958b). These spheroplasts are able to grow, and to synthesize inducible enzymes in the presence of all amino acids except diaminopimelic, showing that this latter amino acid is not essential for protein synthesis.

Lysis through lysine deprivation occurs with Streptococcus faecalis, which contains no diaminopimelic acid, but has lysine instead in its wall mucopeptides (Toennies \& Gallant, 1949; Toennies \& Shockman, 1958). This organism requires to be given eight amino acids, including lysine, for normal growth; the effect of deprivation of each of these amino acids in turn was investigated. With suboptimal concentrations of lysine, the growth curves were very similar to those of the exacting Escherichia coli deprived of diaminopimelic acid, and the organisms lysed after exhaustion of the lysine present. A different phenomenon occurred with organisms depleted of valine or threonine, which are not wall amino acids (Shockman, Kolb \& Toennies, 1958; Toennies et al. 1959; Shockman, 1959a). Exponential growth ceased when valine or threonine was exhausted from the medium, but the cultures continued to increase slowly in optical density and mass up to $40 \mathrm{hr}$. This so-called 'post-exponential growth' was particularly marked in the case of threonine-depleted organisms and was largely due to increase in wall mucopeptide with no concomitant 
protein synthesis. Comparison of the molar ratios of the amino acids in the walls at various stages of growth indicated that the mucopeptides had the same composition at all stages. But when the amino acids were expressed as percentage of wall weight, it was evident that the overall composition of the wall had changed during post-exponential growth, possibly owing to variation of a non-mucopeptide component.

There is a tendency among workers in the field under consideration to examine only the molar ratios of specific wall constituents, not their absolute amounts in terms of percentage composition. This can be misleading, as it does not give a true picture of wall composition. More work of the kind carried out by Shockman and colleagues might lead to a better understanding of various interesting problems connected with cell walls, such as why bacteria harvested during exponential growth are more susceptible than older ones to attack by lytic enzymes (see Douglas \& Parker, 1958). We do not know whether this is simply due to the presence of thicker walls in older organisms, or whether the older walls contain proportionately more enzyme-resistant structures or less enzyme-sensitive groups.

\section{The biosynthesis of mucopeptide}

The experiments just discussed show that synthesis of cell wall and cytoplasmic protein can continue independently in nutritionally-exacting organisms grown under certain conditions; this type of phenomenon has been termed 'unbalanced growth' (McQuillen, 1958a). Another way of dissociating the two types of synthesis is to suspend washed organisms in buffered glucose containing certain amino acids. This approach was used with Staphylococcus aureus by Mandelstam \& Rogers (1958) and Hancock \& Park (1958). Study of the incorporation of radioactive amino acids into walls and proteins of suspensions of $S$. aureus showed that when the amino acids of the suspending media were limited to those of the wall mucopeptides, radioactivity was 'incorporated selectively into the walls; but when 18 amino acids present in proteins were given, both walls and cytoplasmic proteins took up radioactivity. Added chloramphenicol inhibited $94 \%$ of the uptake of amino acids into protein but had no effect on uptake into walls. Penicillin had the opposite effect and selectively inhibited the uptake of amino acids into the wall fraction. Aureomycin was quite unselective; it inhibited both wall and protein synthesis. Mandelstam \& Rogers (1959) showed that the presence of penicillin or bacitracin prevented the usual increase in weight of mucopeptide observed during incubation, and therefore resulted in a genuine inhibition of mucopeptide synthesis.

As might be expected, since penicillin selectively inhibits the synthesis of a component of cell walls, the final result of penicillin action on bacteria growing in normal media is lysis. In fact, the growth curve of Escherichia coli in the presence of penicillin is similar to that produced by diaminopimelic acid deprivation (Meadow et al. 1957). Penicillin lysis has long been known, but the cause of it was not realized until spheroplasts of $E$. coli were produced by growth in penicillin broth containing $10 \%$ sucrose (Lederberg, 1956; Liebermeister \& Kellenberger, 1956; Hahn \& Ciak, 1957). Bizarre forms of various Gram-negative bacteria growing on solid media in the presence of penicillin are well known; these may be regarded as spheroplasts which are stabilised mechanically by the solid medium in which they grow (Lederberg \& St Clair, 1958). Analytical data on L-forms or penicillin-induced 
spheroplasts show that the cells are deficient, but not always completely lacking in diaminopimelic acid and muramic acid (Kandler \& Zehender, 1957; Weibull, 1958; Salton \& Shafa, 1958). Their lipid and polysaccharide components are normal.

Before the site of penicillin action was known Park (1952) observed that when Staphylococcus aureus was grown in the presence of penicillin, certain uridine nucleotides accumulated in the cells. The main nucleotide was uridine diphosphate (UDP) linked through $N$-acetylmuramic acid to a peptide containing lysine, glutamic acid and alanine. At that time, the connexion of this structure with cell walls was not appreciated, nor was muramic acid identified. After the work of Strange \& Powell (1954), Cummins \& Harris, (1956a, $b$, 1958) and Lederberg (1956), a connexion with wall composition was seen (Park \& Strominger, 1957); the nucleotide contained all the components of staphylococcal walls except glucosamine and glycine. The composition of the peptide has now been partly deduced (Fig. 1), although there is as yet no formal proof of the amino acid sequence (Strominger, $1959 a, b$; Strominger \& Threnn, 1959).

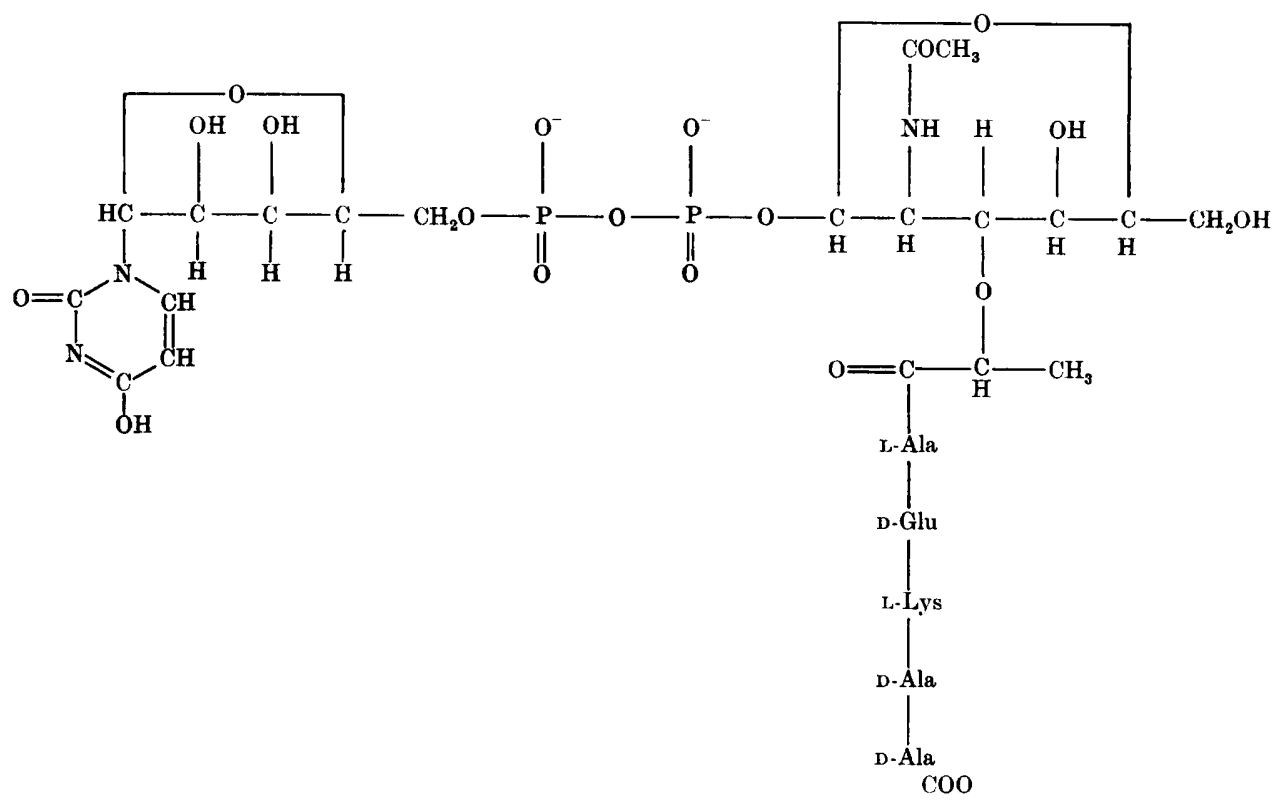

Fig. 1. The structure of a uridine nucleotide which accumulates in penicillin-inhibited Staphylococcus aureus.

The accumulation of other uridine nucleotides in Staphylococcus aureus grown under various conditions has led Strominger to propose a scheme for the biosynthesis of mucopeptide units (summarized by Strominger, 1960). This involves a 'UDP cycle' (Fig. 2) in which uridine nucleotides serve as catalytic carriers. For the purposes of this review, UDP-acetylmuramic acid can be taken as the starting point. This compound was assumed to originate from UDP-acetylglucosamine through UDP-acetylglucosamine-pyruvate (Strominger, 1958). UDP-acetylmuramic acid was one of several nucleotides accumulating in cells grown in the presence of gentian violet; it was suggested that gentian violet acts by inhibiting the attachment of alanine to the muramyl carboxyl group. After depriving $S$. aureus of lysine, 
UDP-acetylmuramyl-L-alanyl-D-glutamate was isolated. An enzyme which catalyses the attachment of lysine to this peptide was partially purified, and found to be specific for L-lysine. D-Cycloserine (oxamycin), another antibiotic known to produce spheroplasts from Escherichia coli (Ciak \& Hahn, 1959), caused accumulation of the uridine peptide which lacked only the two terminal D-alanine molecules (Strominger, Threnn \& Scott, 1959). All the effects of D-cycloserine in different species were competitively reversed by adding D-alanine (see also Shockman, 1959b), but they were not produced by the enantiomorph, L-cycloserine. It seems that this antibiotic acts directly as an analogue of D-alanine. Finally, the last suggested step in the synthesis of wall mucopeptide is a transglycosylation of the UDP-acetylmuramylpeptide with an acceptor, so far unidentified. It is this last step which is supposed by Park \& Strominger to be inhibited by penicillin, but there is as yet no positive evidence for this assumption.

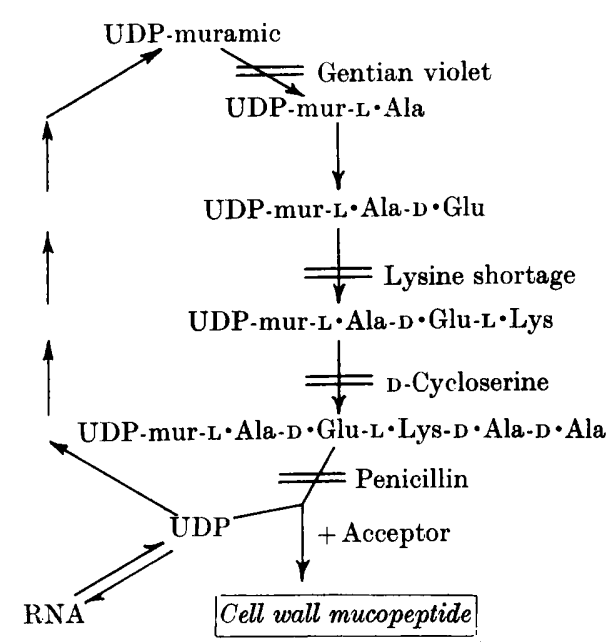

Fig. 2. Scheme for the biosynthesis of part of the cell wall of Staphylococcus aureus.

Other possible sites for penicillin action are inhibition of synthesis of the acceptor, or of transfer of one or more low-molecular weight precursors through the semipermeable cytoplasmic membrane to the site of wall synthesis outside the membrane. Although UDP-peptide accumulation occurs very rapidly after addition of penicillin to growing or resting cultures (Strominger, 1957), this is not the only immediate effect of penicillin. There is also a very rapid release of ultraviolet-absorbing material into the culture fluid with Escherichia coli, which suggests that the osmotic barrier has been disturbed (Prestidge \& Pardee, 1957; Meadow, 1960). Penicillin also interferes with the synthesis of ribonucleic acids in a way quantitatively related to total uridine nucleotide synthesis. This can be explained by the UDP-cycle, since the product of transglycosylation of the UDP-muramyl-peptide would be UDP, a direct precursor of ribonucleic acid. In the presence of penicillin, UDP would be irreversibly trapped in the accumulated uridine peptides and so would be unavailable for synthesis of ribonucleic acids; the inhibition of this synthesis is therefore a secondary result of penicillin action.

A transglycosylation step in mucopeptide synthesis is certainly an attractive 
hypothesis; it is based on the knowledge that similar steps occur in the biosynthesis of low and high molecular-weight polysaccharides, including hyaluronic acid, glucan, cellulose and glycogen; here 'active' sugar fragments are transferred from uridine nucleotides to acceptors (Strominger, 1960). It is possible that this uridine peptide is indeed a precursor of wall mucopeptides, especially because of its content of Damino acids, but it is not the only UDP-peptide found in Staphylococcus aureus treated with penicillin; similar peptides also contain the other staphylococcal wall amino acids, glycine and aspartic acid (Ito, Ishimoto \& Saito, 1959). Direct evidence for the incorporation of any of these peptides as complete units into cell walls has yet to be produced as proof that the uridine peptides are, in fact, immediate cellwall precursors. The method of insertion of glucosamine into the muramyl peptides is not yet known, but is an important step still to be revealed in mucopeptide biosynthesis.

\section{Bacterial wall structure}

Until we know more about the homogeneity of individual units of wall mucopeptides, it is perhaps not very useful to speculate about their possible precursors. The molar ratios of wall constituents are seldom exactly one, and their digestion products are of great variety (Rogers \& Perkins, 1959; Perkins, $1960 \mathrm{~b}$ ). This suggests that whole walls may contain either a mixture of different highly polymerized mucopeptides, or one polymer made from various UDP peptides (monomers), or both. There may well be some favoured monomers which occur in many different organisms; these may be the 'basal units' of walls where there are also various other peptides derived from monomers which are more type-specific. The only uridine peptides which have been isolated from Gram-negative species have been found in a diaminopimelic acid-requiring mutant of Escherichia coli grown under unspecified conditions (Strominger, Scott \& Threnn, 1959). One peptide had the same amino acid sequence as in the nucleotide peptide of penicillin-grown Staphylococcus aureus (Fig. 1) except that meso-diaminopimelic acid took the place of lysine. Under conditions of diaminopimelic deprivation, the peptide contained only L-alanyl-D-glutamic acid. Possibly the sequence acetylmuramyl-L-alanine-D-glutamic-(diaminopimelic or lysine)D-alanine-D-alanine may be a favoured monomer which provides the 'basal unit' of walls of both Gram-positive and Gram-negative bacteria.

Perhaps a part at least of the mucopeptide structure can be envisaged as a backbone of $N$-acetylglucosamine- $N$-acetylmuramate, possibly in alternating $(1 \rightarrow 4)$, $(1 \rightarrow 6) \beta$-glycosidic linkages, bound by peptide links through the carboxyl groups of muramic acid to various amino acids. This peptide link is often, but not invariably, through alanine: exceptions are the muramyl-glycyl sequence identified by Perkins \& Rogers (1959) in partial acid-hydrolysates of walls of Micrococcus lysodeikticus, and the alanine-free peptides which were found in enzymic digests of Escherichia coli walls by Work \& Lecadet (1960). The sugars of walls are also linked to the hexosamines and often are present as high molecular-weight lipopolysaccharides which are responsible for the group-specific antigenic properties of cell walls. Little is known about the sequences or compositions of the peptide chains except in the case of the uridine-peptides already described. There are few free amino groups in Gram-positive walls, usually that of alanine and one amino group of lysine or diaminopimelic acid (Ingram \& Salton, 1957). Many of the pairs of amino groups of 
lysine and diaminopimelic acid of $\boldsymbol{E}$. coli are not free to react with fluorodinitrobenzene (Salton, 1957b; Work \& Lecadet, 1960). This suggests that these amino groups act as cross-linking agents between adjacent chains, or form cyclic peptides. The cross-linking of chains is known to be one of the best ways of producing rigid structures, and this may be the function of the two amino acids lysine and diaminopimelic acid, which are the only long-chain amino acids in the mucopeptide structure. Lysine and diaminopimelic acid have identical chains-the latter compound having just one more carboxyl group; they appear to be mutually exclusive in the walls of Gram-positive organisms. Glutamic acid is invariably present in mucopeptides, but whether in $\alpha$ - or $\gamma$-linkages is not known. As a whole, the amino acids of mucopeptides present plenty of opportunity for cross-linking or cyclization; if not doubly linked they could tend to form strong non-covalent links either with adjacent mucopeptides or with other charged molecules such as the teichoic acids.

\section{Table 4. Amino acid components of walls of certain species of bacteria}

Glutamic acid and alanine were always present and are not included.

\begin{tabular}{|c|c|c|c|c|c|}
\hline \multirow[b]{2}{*}{ Genus } & \multirow{2}{*}{$\begin{array}{c}\text { No. of } \\
\text { species } \\
\text { examined }\end{array}$} & \multirow[b]{2}{*}{ Lysine } & \multicolumn{2}{|c|}{ Diaminopimelic acid } & \multirow[b]{2}{*}{ Glycine } \\
\hline & & & Meso & LL. & \\
\hline Staphylococcus & 9 & + & - & - & + \\
\hline Micrococcus & $2^{*}$ & - & + & - & + \\
\hline Propionibacterium & 4 & - & - & + & + \\
\hline Propionibacterium & 1 & - & + & - & - \\
\hline Bacillus & 3 & - & + & - & - \\
\hline Clostridium & 1 & - & - & + & + \\
\hline Nocardia & 4 & - & + & - & - \\
\hline Nocardia & 1 & - & - & + & + \\
\hline Micromonospora & 5 & - & + & + & + \\
\hline
\end{tabular}

The D-configuration of the glutamic acid and alanine in walls is of great interest; it may account both for the stability of the mucopeptides against attack by proteolytic enzymes, and for the obviously different mechanisms of peptide biosynthesis in walls and in cytoplasmic proteins. The most common form of diaminopimelic acid is the meso-isomer with a D-configuration at one end and an $\mathrm{L}$ the other. In the Escherichia coli uridine-peptide, meso-diaminopimelic acid occurs between D-alanine and D-glutamic acid and might be linked in peptide bonds through its D 'end'. The unreacted L-end of diaminopimelic acid might either cross-link with L-amino acids in other peptides, or might retain the biological reactivity of the peptide for further biosynthesis by its capacity to react with enzymes in the usual L-configuration. This biological reactivity occurs in the decarboxylation and racemization of mesodiaminopimelic acid (p. 170), where the $\mathrm{L}$ 'end' of the molecule is thought to react with the enzymes. An interesting point arising from a study of the data about cellwall composition is that where walls contain LL-diaminopimelic acid, glycine is invariably present, but when meso-diaminopimelic occurs, glycine is seldom found (Table 4). Walls of the species which contain LL-diaminopimelic acid have not yet been examined in detail, but if one assumes that they contain the $\mathrm{D}$-isomers of 
glutamic acid and alanine, it may be suggested that glycine, with its freely rotating amino and carboxyl groups might be able to align LL-diaminopimelic acid in a peptide chain containing $\mathrm{D}$-amino acids.

\section{CONCLUSION}

In dealing with a structure-the cell wall-found in so many different types of organism, it is obvious that the work of a few years described here cannot give more than a preliminary sketch of the subject. This review, is therefore, not an attempt to cover the complete field, but deals only with certain topics in the hope that it may serve as a pointer for future work. One obvious need is for detailed analyses of mucopeptide components from a wide variety of bacterial species. Without this, no valid generalizations can be made.

The material of this review was used in two lectures given at University College, London, in February 1960.

\section{REFERENCES}

ANTIA, M., HoARe, D. S. \& Work, E. (1957). The stereoisomers of $\alpha, \epsilon$-diaminopimelic acid. 3. Properties and distribution of diaminopimelic acid racemase, an enzyme causing interconversion of the LL and meso isomers. Biochem. J. 65, 448.

Antia, M. \& Work, E. (1961). Oxidation of meso-diaminopimelic acid by certain atypical sporulating species of bacteria. J. gen. Microbiol. 26, in Press.

Armstrong, J. J., Baddiley, J., Buchanan, J. G., Carss, B. \& Greenberg, G. R. (1958). Isolation and structure of ribitol phosphate derivatives (teichoic acids) from bacterial cell walls. J. chem. Soc. 4344 .

Bauman, N. \& Davis, B. D. (1957). Selection of auxotrophic bacterial mutants through diaminopimelic acid or thymine deprival. Science, 126, 170.

Borek, E. \& RYAN, A. (1959). Induction of phage formation in protoplasts derived from a lysogenic organism. Biochim. biophys. Acta, 36, 386.

Brenner, S. et al. (1958). Bacterial protoplasts. Nature, Lond. 181, 1713.

Brown, D. D. \& KozLoff, L. M. (1957). Morphological localization of the bacteriophage tail enzyme. J. biol. Chem. 225, 1.

BrumfitT, W. (1959). The mechanism of development of resistance to lysozyme by some gram-positive bacteria. Brit. J. exp. Path. 40, 441.

Butler, J. A. V., Crathorn, A. R. \& Hunter, G. D. (1958). The site of protein synthesis in Bacillus megaterium. Biochem. J. 69, 544.

CraK, J. \& HAHN, F. E. (1959). Studies on the modes of action of cycloserine and its Lstereoisomer. Antibiot. \& Chemother. 9, 47.

Cummins, C. S. (1956). The chemical composition of the bacterial cell wall. Int. Rev. Cytol. $5,25$.

Cummins, C. S. \& Harris, H. (1956a). The chemical composition of the cell wall in some gram-positive bacteria and its possible value as a taxonomic character. J. gen. Microbiol. 14, 583.

Cummins, C. S. \& Harris, H. $(\mathbf{1 9 5 6} b)$. The relationship between certain members of the staphylococcus-micrococcus group as shown by their cell wall composition. Int. Bull. bact. Nomen. \& Taxon. 6, 111.

Cummins, C. S. \& Harris, H. (1958). Studies on the cell-wall composition and taxonomy of Actinomycetales and related groups. J. gen. Microbiol. 18, 173.

Davis, B. D. (1952). Biosynthetic interrelations of lysine, diaminopimelic acid, and threonine in mutants of Escherichia coli. Nature, Lond. 169, 534.

Dewey, D. L. \& Work, E. (1952). Diaminopimelic acid decarboxylase. Nature, Lond. 169, 533. 
Dewey, D. L., Hoare, D. S. \& Work, E. (1954). Diaminopimelic acid decarboxylase in cells and extracts of Escherichia coli and Aerobacter aerogenes. Biochem. J. 58, 523.

Douglas, H. W. \& Parker, F. (1958). Electrophoretic studies on bacteria. 3. The growth cycle of Bacillus megaterium, the behaviour of cells and the changes produced by lysozyme. Biochem. J. 68, 99.

Fleming, A. (1922). On a remarkable bacteriolytic element found in tissues and secretions. Proc. Roy. Soc. B, 93, 306.

Fisher, K. W. (1959). Bacteriophage penetration and its relation to host cell wall structure Proc. Roy. phys. Soc., Edinb. 28, 91.

Freimer, E. H., Krause, R. M. \& McCarty, M. (1959). Studies of $\mathrm{L}$ forms and protoplasts of group A streptococci. 1. Isolation, growth, and bacteriologic characteristics. J. exp. Med. 110, 853.

Gerhardt, P. (1959). The protoplast membrane of bacteria. Univ. Mich. med. Bull. 25, 148.

Ghuysen, J. M. \& Salton, M. R. J. (1960). Acetylhexosamine compounds enzymically released from Micrococcus lysodeikticus cell walls. I. Isolation and composition of acetylhexosamine and acetylhexosaminepeptide complexes. Biochim. biophys. Acta, 40, 462.

Gilby, A. R., Few, A. V. \& McQuillen, K. (1958). The chemical composition of the protoplast membrane of Micrococcus lysodeikticus. Biochim. biophys. Acta, 29, 21.

GiLvarG, C. (1957). $N$-succinyl-L-diaminopimelic acid, an intermediate in the biosynthesis of diaminopimelic acid. Biochim. biophys. Acta, 24, 216.

Gilvarg, C. (1958). The enzymatic synthesis of diaminopimelic acid. J. biol. Chem. 233, 1501.

Gilvarg, C. (1959). $N$-succinyl-L-diaminopimelic acid. J. biol. Chem. 234, 2955.

Glaser, L. (1960). Glutamic acid racemase from Lactobacillus arabinosus. J. biol. Chem. 235, 2095.

Hahn, F. E. \& Ciak, J. (1957). Penicillin-induced lysis of Escherichia coli. Science, 125, 119.

Hancock, R. \& Park, J. 'T. (1958). Cell wall synthesis by Staphylococcus aureus in the presence of chloramphenicol. Nature, Lond. 181, 1050.

HoARE, D. S. \& Work, E. (1955). The stereoisomers of $\alpha, \epsilon$-diaminopimelic acid: their distribution in nature and behaviour towards certain enzyme preparations. Biochem. $J$. 61, 562.

HoARE, D. S. \& Work, E. (1957). The stereoisomers of $\alpha, \epsilon$-diaminopimelic acid. 2. Their distribution in the bacterial order Actinomycetales and in certain Eubacteriales. Biochem. J. 65, 441.

Holdsworth, E. S. (1951). A polysaccharide isolated from Corynebacterium diphtheriae. Biochem. J. 49, xiv.

Holme, T., Malmborg, A.-S. \& Cota-Robles, E. (1960). Antigens of spheroplast membrane preparations from Escherichia coli B. Nature, Lond. 185, 57.

IKawa, M. \& SNell, E. E. (1960). Cell wall composition of lactic acid bacteria. J. biol. Chem. 235, 1376.

INGRAM, V. M. \& SALton, M. R. J. (1957). The action of fluorodinitrobenzene on bacterial cell walls. Biochim. biophys. Acta, 24, 9.

Iто, E., Isнiмото, N. \& SaIto, M. (1959). Uridine diphosphate $\mathbf{N}$-acetylamino sugar compounds from Staphylococcus aureus strain 209P. 1. Amino acid constituents. Arch. Biochem. Biophys. 80, 431.

JACOB, F. \& FuERST, C. R. (1958). The mechanism of lysis by phage studied with defective lysogenic bacteria. J. gen. Microbiol. 18, 518.

KANDLER, O. \& ZEHENDER, C. (1957). Über das Vorkommen von $\alpha, \epsilon$-diaminopimelinsäure bei verschiedenen L-Phasentypen von Proteus vulgaris und bei den pleuropneumonie-ähnlichen Organismen. Z. Naturforsch. $12 b, 725$.

Kellenberger, E. \& RYter, A. (1958). Cell wall and cytoplasmic membrane of Escherichia coli. J. biophys. biochem. Cytol. 4, 323.

Kindler, S. H. \& Gilvarg, C. (1960). $N$-succinyl-L-diaminopimelic acid deacylase. $J$. biol. Chem. 235, 3532. 
Kocr, G. \& Dreyer, W. J. (1958). Characterization of an enzyme of phage $T_{2}$ as a lysozyme. Virology, 6, 291.

Koch, G. \& Jordan, E. M. (1957). Killing of $E$. coli B by phage-free $\mathrm{T}_{2}$ lysates. Biochim. biophys. Acta, 25, 437.

Kосн, G. \& Weidel, W. (1956). Abspaltung chemischer Komponenten der Coli-Membran durch daran adsorbierte Phagen. 1. Mitt: Allgemeine Charakterisierung des Effekts und Partialanalyse einer der abgespaltenen Komponenten. Z. Naturforsch. $11 b, 345$.

KraUse, R. M. (1958). Studies on the bacteriophages of haemolytic streptococci. II. Antigens released from the streptococcal cell wall by a phage-associated lysin. J. exp. Med. 108, 803.

Lederberg, J. (1956). Bacterial protoplasts induced by penicillin. Proc. nat. Acad. Sci., Wash. 42, 574.

Lederberg, J. \& St. Clair, J. (1958). Protoplasts and L-type growth of Escherichia coli. J. Bact. 75, 143.

Liebermeister, K. \& Kellenberger, E. (1956). Studien zur L-Form der Bakterien. Z. Naturforsch. 11 b, 200.

MandelstaM, J. \& Rogers, H. J. (1958). Chloramphenicol-resistant incorporation of amino-acids into Staphylococci and cell wall synthesis. Nature, Lond. 181, 956.

Mandelstam, J. \& Rogers, H. J. (1959). The incorporation of amino acids into the cell wall mucopeptide of Staphylococci and the effect of antibiotics on the process. Biochem. J. 72, 654.

MaXted, W. R. (1957). The active agent in nascent phage lysis of Streptococci. J. gen. Microbiol. 16, 584.

McCARTy, M. (1952). The lysis of group A hemolytic streptococci by extracellular enzymes of Streptomyces albus. II. Nature of the cellular substrate attacked by the lytic enzymes. J. exp. Med. 96, 569.

MCQuilLen, K. (1955). Bacterial protoplasts: growth and division of protoplasts of Bacillus megaterium. Biochim. biophys. Acta, 18, 458.

McQuillen, K. (1958a). Lysis resulting from metabolic disturbance. J. gen. Microbiol. 18, 498.

MCQUillen, K. (1958b). Bacterial 'protoplasts': Effects of diaminopimelic acid deprival and penicillin addition compared in Escherichia coli. Biochim. biophys. Acta, 27, 410.

MEaDow, P. (1960). Effects of penicillin on a mutant of Escherichia coli requiring diaminopimelic acid. Biochem. J. 76, 8 P.

Meadow, P. \& Work, E. (1958). Bacterial transamination of the stereoisomers of diaminopimelic acid and lysine. Biochim. biophys. Acta, 28, 596.

Meadow, P. \& Work, E. (1959). Biosynthesis of diaminopimelic acid and lysine in Escherichia coli. 2. Incorporation of $\left({ }^{14} \mathrm{C}\right)$ diaminopimelic acid, lysine and glucose. Biochem. J. 72, 400.

Meadow, P., Hoare, D. S. \& Work, E. (1957). Interrelationships between lysine and $\alpha, \epsilon$-diaminopimelic acid and their derivatives and analogues in mutants of Escherichia coli. Biochem. J. 66, 270.

MrTCheld, P. \& MoYLe, J. (1957). Autolytic release and osmotic properties of 'protoplasts' from Staphylococcus aureus. J. gen. Microbiol. 16, 184.

Murphy, J. S. (1957). A phage-associated enzyme of Bacillus megaterium which destroys the bacterial cell wall. Virology, 4, 563 .

PaniJel, J. \& Huppert, J. (1957). Mise en évidence de prolysines endogènes dans les bactériophages. Ann. Inst. Pasteur, 93, 352.

Park, J. T. (1952). Uridine-5'-pyrophosphate derivatives. I. Isolation from Staphylococcus aureus: II. A structure common to three derivatives; III. Amino-acid containing derivatives. J. biol. Chem. 194, 877, 885, 897.

Park, J. T. \& Strominger, J. L. (1957). Mode of action of penicillin. Biochemical basis for the mechanism of action of penicillin and for its selective toxicity. Science, $125,99$.

Perkins, H. R. (1960 a). The structure of a disaccharide liberated by lysozyme from the cell walls of Micrococcus lysodeikticus. Biochem. J. 74, 182. 
Perkins, H. R. (1960b). Substances reacting as hexosamines and as $\boldsymbol{N}$-acetyl hexosamine liberated from bacterial cell walls by lysozyme. Biochem. J. 74, 186.

Perkins, H. R. \& Rogers, H. J. (1959). The products of the partial acid hydrolysis of the mucopeptide from cells wall of Micrococcus lysodeikticus. Biochem. J. 72, 647.

Peterkofsky, B. \& Gilvarg, C. (1959). Purification and properties of $N$-succinyl-diaminopimelic-glutamic transaminase. Fed. Proc. 18, 301.

Powell, J. F. \& Strange, R. E. (1953). Biochemical changes occurring during the germination of bacterial spores. Biochem. J. 54, 205.

Powell, J. F. \& Strange, R. E. (1956). Biochemical changes occurring during sporulation in Bacillus species. Biochem. J. 63, 661 .

Prestidge, L. S. \& Pardee, A. B. (1957). Induction of bacterial lysis by penicillin. $J$. Bact. 74, 48.

Ralston, D. J., Lieberman, M., Baer, B. \& Krueger, A. P. (1957). Staphylococcal virolysin, a phage-induced lysin. Its differentiation from the autolysin of normal cells. J. gen. Physiol. 40, 791.

Richmond, M. H. (1959a). Formation of a lytic enzyme by a strain of Bacillus subtilis. Biochim. biophys. Acta, 33, 78.

Rrchmond, M. H. (1959 b). Properties of a lytic enzyme produced by a strain of Bacillus subtilis. Biochim. biophys. Acta, 33, 92.

Richmond, M. H. \& Perkins, H. R. (1960). Possible precursors for the synthesis of muramic acid by Staphylococcus aureus 524. Biochem. J. 76, 1p.

Rhuland, L. E. (1957). Role of $\alpha, \epsilon$-diaminopimelic acid in the cellular integrity of Escherichia coli. J. Bact. 73, 778.

Rhuland, L. E. (1960). $\alpha, \epsilon$-diaminopimelic acid: its distribution, synthesis and metabolism. Nature, Lond. 185, 224.

Rhuland, L. E., Work, E., Denman, R. F. \& Hoare, D. S. (1955). The behaviour of the isomers of $\alpha, \epsilon$-diaminopimelic acid on paper chromatograms. J. Amer. chem. Soc. 77, 4844.

Rogers, H. J. \& Perkins, H. R. (1959). Cell-wall mucopeptides of Staphylococcus aureus and Micrococcus lysodeikticus. Nature, Lond. 184, 520.

RYDoN, H. N. (1948). D-Amino acids in microbiological chemistry. 'The relation of optical form to biological activity in the amino acids series.' Biochem. Soc. Symp. 1, 40.

SAlton, M. R. J. (1952a). Studies of the bacterial cell wall. III. Preliminary investigation of the chemical constitution of the cell wall of Streptococcus faecalis. Biochim. biophys. Acta, 8, 510.

SALTON, M. R. J. (1952b). Cell wall of Micrococcus lysodeikticus as the substrate of lysozyme. Nature, Lond. 170, 746.

Salton, M. R. J. (1956a). Bacterial cell walls. In Bacterial Anatomy, Symp. Soc. gen. Microbiol. 6, 81.

Salton, M. R. J. (1956b). Studies of the bacterial cell wall. V. The action of lysozyme on cell walls of some lysozyme-sensitive bacteria. Biochim. biophys. Acta, 22, 495.

Salton, M. R. J. (1957 a). The properties of lysozyme and its action on microorganisms. Bact. Rev. 21, 82.

SAlton, M. R. J. (1957b). Cell-wall amino acids and amino-sugars. Nature, Lond. 180, 338.

SALton, M. R. J. (1958). The lysis of micro-organisms by lysozyme and related enzymes. J. gen. Microbiol. 18, 481.

Salton, M. R. J. \& Gruysen, J. M. (1959). The structure of di- and tetra-saccharides released from cell walls by lysozyme and Streptomyces $F_{1}$ enzyme and the $\beta(1 \rightarrow 4)$ $N$-acetylhexosaminidase activity of these enzymes. Biochim. biophys. Acta, 36, 552.

SALton, M. R. J. \& HorNe, R. W. (1951). Studies of the bacterial cell wall. II. Methods of preparation and some properties of cell walls. Biochim. biophys. Acta, 7, 177.

Salton, M. R. J. \& Marshall, B. (1959). The composition of the spore wall and the wall of vegetative cells of Bacillus subtilis. J. gen. Microbiol. 21, 415.

Salton, M. R. J. \& Shafa, F. (1958). Some changes in the surface structure of gramnegative bacteria induced by penicillin action. Nature, Lond. 181, 1321. 
Shockman, G. D. $(1959 a)$. Bacterial cell wall synthesis: The effect of threonine depletion. J. biol. Chem. 234, 2340.

Shockman, G. D. $(\mathbf{1 9 5 9} b)$. Reversal of cycloserine inhibition by D-alanine. Proc. Soc. exp. Biol., N.Y., $101,693$.

Shockman, G. D., Kolb, J. J. \& Toennies, G. (1958). Relations between bacterial cell wall synthesis, growth phase, and autolysis. J. biol. Chem. 230, 961.

Strange, R. E. (1956). The structure of an amino sugar present in certain spores and bacterial cell walls. Biochem. $J .64,23$ P.

Strange, R. E. (1959). Cell wall lysis and the release of peptides in Bacillus species. Bact. Rev. 23, 1.

Strange, R. E. \& Dark, F. A. (1956). The composition of the spore coats of Bacillus megaterium, B. subtilis and B. cereus. Biochem. J. 62, 459.

Strange, R. E. \& Kent, L. H. (1959). The isolation, characterization and chemical synthesis of muramic acid. Biochem. J. 71, 333.

Strange, R. E. \& Powell, J. F. (1954). Hexosamine-containing peptides in spores of Bacillus subtilis, B. megaterium and B. cereus. Biochem. J. 58, 80.

Strominger, J. L. (1957). Microbial uridine-5'-pyrophosphate $N$-acetylamino sugar compounds. 1. Biology of the penicillin-induced accumulation. J. biol. Chem. 224, 509.

Strominger, J. L. (1958). Enzymic transfer of pyruvate to uridine diphosphoacetylglucosamine. Biochim. biophys. Acta, 30, 645.

Strominger, J. L. (1959 $a$ ). The amino acid sequence in the uridine nucleotide-peptide from Staphylococcus aureus. C.R. Lab. Carlsberg, 31, 181.

Strominger, J. L. (1959b). Accumulation of uridine and cytidine nucleotides in Staphylococcus aureus inhibited by gentian violet. J. biol. Chem. 234, 1520.

Strominger, J. L. (1960). Mononucleotide anhydrides and related compounds as intermediates in metabolic reactions. Physiol. Rev. 40, 55.

Strominger, J. L. \& Threnn, R. H. (1959). The optical configuration of the alanine residues in a uridine nucleotide and in the cell wall of Staphylococcus aureus. Biochim. biophys. Acta, 33, 280.

Strominger, J. L., Scott, S. S. \& Threnn, R. H. (1959). Isolation from E. coli of a uridine nucleotide containing diaminopimelic acid. Fed. Proc. 18, abstract 1323.

Strominger, J. L., Threnn, R. H. \& Scott, S. S. (1959). Oxamycin, a competitive antagonist of the incorporation of $\boldsymbol{D}$-alanine into a uridine nucleotide in Staphylococcus aureus. J. Amer. chem. Soc. 81, 3803.

'Thorne, C. B. (1956). Capsule formation and glutamyl polypeptide synthesis by Bacillus anthracis and Bacillus subtilis. In Bacterial Anatomy. Symp. Soc. gen. Microbiol. 6, 68.

Thorne, C. B., Gomez, C. G. \& Housewright, R. D. (1955). Transamination of $D$-amino acids by Bacillus subtilis. J. Bact. 69, 357.

'Toennies, G. \& Gallant, D. L. (1949). Bacterimetric studies: II. The role of lysine in bacterial maintenance. J. biol. Chem. 177, 831.

Toennies, G. \& Shockman, G. D. (1958). Growth chemistry of Streptococcus faecalis, in Colloquia, 4th int. Congr. Biochem. 13, 365.

Toennies, G., Bakay, B. \& Shockman, G. D. (1959). Bacterial composition and growth phase. J. biol. Chem. 234, 3269.

Vennes, J. W. \& Gerhard, P. (1959). Antigenic analysis of cell structures isolated from Bacillus megaterium. J. Bact. 77, 58.

Vincenzi, L. (1887). Ueber die chemischen Bestandtheile der Spaltpilze. Hoppe-Seyl. Z. $11,181$.

Weibule, C. (1958). Bacterial protoplasts. Annu. Rev. Microbiol. 12, 1.

Weibule, C. \& Bergstrom, L. (1958). The chemical nature of the cytoplasmic membrane and cell wall of Bacillus megaterium, Strain M. Biochim. biophys. Acta, 30, 340.

Weidel, W. (1958). Bacterial viruses. Annu. Rev. Microbiol. $12,27$.

Weidel, W. \& Primosigh, J. (1957). Die gemeinsame Wurzel der Lyse von Escherichia coli durch Penicillin oder durch Phagen. Z. Naturforsch. $12 b, 421$.

Weidel, W. \& Primosigh, J. (1958). Biochemical parallels between lysis by virulent phage and lysis by penicillin. J. gen. Microbiol. 18, 513.

Weidel, W., Frank, H. \& Martin, H. H. (1960). The rigid layer of the cell wall of Escherichia coli Strain B. J. gen. Microbiol. 22, 158. 
WESTPhal, O. (1960). Récentes recherches sur la chimie et la biologie des endotoxines des bactéries a Gram négatif. Ann. Inst. Pasteur, 98, 789.

Work, E. (1951). The isolation of $\alpha, \epsilon$-diaminopimelic acid from Corynebacterium diphtheriae and Mycobacterium tuberculosis. Biochem. J. 49, 17.

Work, E. (1955). The action of L-amino acid oxidases on the optical isomers of $\alpha, \epsilon-$ diaminopimelic acid. Biochim. biophys. Acta, 17, 410.

Work, E. (1957). Biochemistry of the bacterial cell wall. Nature, Lond. 179, 841.

Work, E. (1959). The action of a lytic enzyme from spores of a Bacillus sp. on various species of bacteria. Ann. Inst. Pasteur, 96, 468.

Work, E. (1960). Properties of $\lambda$-endolysin, the lytic enzyme in lysates of lysogenic Escherichia coli. Biochem. J. 76, $38 \mathrm{P}$.

Work, E. \& Dewey, D. L. (1953). The distribution of $\alpha, \epsilon$-diaminopimelic acid among various micro-organisms. J. gen. Microbiol. 9, 394.

Work, E. \& LeCADET, M. (1960). Digestion of cell walls of Escherichia coli and Bacillus megaterium by $\lambda$-endolysin or lysozyme. Biochem. $J .76,39 \mathrm{P}$.

Work, E., Birnbaum, S. M., Winitz, M. \& Greenstein, J. P. (1955). Separation of the three isomeric components of synthetic $\alpha, \epsilon$-diaminopimelic acid. J. Amer. chem. Soc. 77, 1916.

Zilliken, F. (1959). Chemistry of bacterial cell walls. Fed. Proc. 18, 966. 